\title{
Intercropping Sorghum (Sorghum bicolor L.) and Cowpea (Vigna unguiculata L.): Effect of Bradyrhizobium Inoculation and Fertilization on Minerals Composition of Sorghum Seeds
}

\author{
Ekhlas M. Musa, ${ }^{1}$ Elsiddig A. E. Elsheikh, ${ }^{1}$ \\ Isam A. Mohamed Ahmed, ${ }^{2,3}$ and Elfadil E. Babiker ${ }^{2}$ \\ ${ }^{1}$ Department of Soil Sciences and Environment, Faculty of Agriculture, University of Khartoum, Shambat 14413, Sudan \\ ${ }^{2}$ Department of Food Science and Technology, Faculty of Agriculture, University of Khartoum, Shambat 14413, Sudan \\ ${ }^{3}$ Department of Applied Resources Chemistry, Faculty of Agriculture, Tottori University, Tottori 680-8553, Japan
}

Correspondence should be addressed to Elfadil E. Babiker, elfadilbabiker@yahoo.com

Received 9 August 2011; Accepted 14 September 2011

Academic Editors: O. Ferrarese-Filho and P. Soengas

Copyright ( 12012 Ekhlas M. Musa et al. This is an open access article distributed under the Creative Commons Attribution License, which permits unrestricted use, distribution, and reproduction in any medium, provided the original work is properly cited.

\begin{abstract}
This investigation was carried out in order to gain a better understanding of the effect of Bradyrhizobium inoculation and fertilization on the nutritional values of macro- and micronutrients of sorghum intercropped with cowpea in the field under rainfed conditions. The results of the present study demonstrated that intercropping, Bradyrhizobium inoculation, and $\mathrm{N}$ and $\mathrm{P}$ fertilization had significant effect on the mineral status of sorghum seeds. Intercropping significantly $(P \leq 0.05)$ increased Ca, $\mathrm{Mg}, \mathrm{Cu}, \mathrm{Mn}$, and Fe contents of sorghum seeds, while it had no effect on the concentration of P, K, Na, and $\mathrm{Zn}$ in the sorghum seeds. However, Bradyrhizobium inoculation did not enhanced the most of minerals content of sorghum in both cropping systems; it slightly reduced the phosphorous content of sorghum seeds in the two cropping systems. Results of application of $\mathrm{N}$ and $\mathrm{P}$ fertilizers separately or combined with Bradyrhizobium showed fluctuated effect on the mineral contents in both cropping systems and both seasons.
\end{abstract}

\section{Introduction}

Intercropping legumes and nonlegumes is an agricultural practice of cultivating two or more crops in the same place of land at the same time which is commonly practiced in many parts of the world in order to increase the productivity per unit area of the land [1]. The crops are not necessarily sown at the same time and their harvest time may be quite different, but they are simultaneously grown for significant growing periods [2]. Moreover, intercropping allows efficient use of both space and time to optimize beneficial effects [3]. According to Campbel [4] intercropping promotes diversification and allows greater flexibility in adjusting to short- and long-term changes in the production and marketing situations, and also intercropping provides better weed control and reduces pest and disease incidence [5]. Furthermore intercropping is a popular cropping system among small scale farmers in the tropics [6]. Cereal/legume intercropping increased dry-matter production and grain yield more than their monocultures. The $\mathrm{N}$ transfer from legume to cereal increased the cropping system's yield and efficiency of $\mathrm{N}$ uses. The taller cereal reduces biological $\mathrm{N}$ fixation and yield of the associated legume [7]. According to Sangakkara [8], the competitive relationships between the non-legume and the legume affected the growth and yield of the leguminous crops in close proximity.

Sorghum (Sorghum bicolor L. Moench) belongs to the family Gramineae, including both wild and cultivated sorghum. Sorghum is the fifth important crop among the cereals in the world following rice, wheat, maize, and barley in total area planted and production [9]. Sorghum is a principal cereal that forms an important staple diet throughout the semiarid Asian and African regions [10]. It is grown in regions receiving $300-1200 \mathrm{~mm}$ rainfall and 
in soils of $\mathrm{pH}$ range 5.0-10.0 [11]. Sorghum is grown for grain, forage, syrup, and sugar. In 2004 the total production of sorghum in the world was 57924 thousand tones and in Sudan was 2600 thousand tones [12]. The total consumption of sorghum closely follows the global patterns of output, since most of it is consumed in the countries where it is grown.

Increasing population and the consequent increased demand for food production and food quality in the world require that proposed agronomic strategies for improvement should, in general, avoid high input costs. Biofertilizers such as rhizobia and mycorrhiza are steadily receiving increased attention and recognition from scientists. This could be attributed to the fact that they pose no ecological threats, usually have a longer-lasting effect, and, if properly managed, can outyield recommended doses of chemical fertilizers [13]. The latter effect is of special importance for countries like Sudan, with predominantly low-input agricultural systems of production. Breeding programmes were started all over the world to improve seed quality of legumes. Fertilizer programmes were also established in Sudan to serve the same purpose $[14,15]$. Inoculation of soybean by Bradyrhizobium japonicum significantly increased nodulation and yield and seed quality [16]. Elemental sulphur has a variety of uses as soil amendment. The oxidation of elemental sulphur to $\mathrm{H}_{2} \mathrm{SO}_{4}$ is particularly beneficial in alkaline soils to reduce the $\mathrm{pH}$, supply $\mathrm{SO}_{4}$ to plants, and make phosphorus and micronutrients more available and reclaim soils [17]. The effectiveness of elemental sulphur depends upon the soil type, $\mathrm{pH}$, organic matter content, clay minerals, depth of soil profile, and drainage status. However, Ghani et al. [18] reported that microbial population in soil is not a limiting factor in elemental sulphur oxidation. Efforts throughout the world are directed towards improving the nutritional quality of crops by decreasing the level of antinutrients and improving the nutritional quality of beans and grains. Intercropping, breeding, fertilization, and genetic engineering programmes are directed towards improving seed quality. The aim of this study was to determine the effect of inoculation with Bradyrhizobium strain, intercropping, $\mathrm{N}$ and $\mathrm{P}$ fertilization, and their interaction on minerals composition of sorghum seeds.

\section{Materials and Methods}

2.1. Materials. Bradyrhizobium strain TAL 169 as a charcoal inoculant was obtained from the National Center for Research, Environment and Natural Resources Research Institute, Biofertilization Department, Khartoum, Sudan. Seeds were wetted using 40\% gum Arabic solution and then mixed thoroughly with the charcoal-based inoculum of Bradyrhizobium. Inoculated seeds were left to dry for few minutes in shade. Seeds of cowpea (Vigna unguiculata L. Walp) were obtained from the local market of Abu Naama, whereas seeds of sorghum (Sorghum bicolor L. Moench) (Tabat variety) were obtained from the Sudanese Arabian Company. The germination test of both crops indicated that germination percentage was above $90 \%$ of the seeds that were viable. Unless otherwise stated all chemicals used in this study are of reagent grade.

2.2. Field Experiments and Experimental Site. A field experiment was conducted for two consecutive seasons (2004 and 2005 ) to study the effect of intercropping, inoculation, $\mathrm{N}$ and $\mathrm{P}$ fertilization on physical and chemical properties of sorghum seeds. The experimental site lies at the Demonstration Farm of the Faculty of Agriculture, University of Sennar, Abu Naama, $400 \mathrm{Kms}$ Southeast of Khartoum. It lies in the semi tropical savanna, at latitude $12^{\circ} 44^{\prime} \mathrm{N}$ and longitude $34^{\circ} 7^{\prime} \mathrm{E}$. The area is dominated by rainfed agriculture where sorghum, sesame, and groundnut are the main crops grown.

2.3. Experimental Design and Treatments. The experimental layout was arranged in split-split plot design with six replicates.

The following treatments were assigned to the main plots:

(1) uninoculated (control);

(2) inoculated with Bradyrhizobium strain.

The following cropping systems were assigned to the subplots:

(1) cowpea (monocropping system);

(2) cowpea/sorghum (intercropping system);

(3) sorghum (monocropping system).

The following fertilizers were assigned to the subsubplots:

(1) no fertilizers (control);

(2) $20 \mathrm{~kg} \mathrm{~N} / \mathrm{ha}$;

(3) $50 \mathrm{~kg} \mathrm{P}_{2} \mathrm{O}_{5} / \mathrm{ha}$ as triple superphosphate TSP.

Five seeds of inoculated or uninoculated cowpea in conjunction with sorghum were sown by hand on the eastern side of the ridge in holes $30 \mathrm{~cm}$ apart, which were later thinned to three plants per hole for both crops. The crops were grown in alternate, single rows (raw intercropping). To avoid rhizobial cross-contamination, plots of uninoculated seeds were sown first. To the inoculated and uninoculated seeds the soil was amended with $20 \mathrm{~kg} \mathrm{~N} / \mathrm{ha}$ and $50 \mathrm{~kg}$ $\mathrm{P}_{2} \mathrm{O}_{5} /$ ha as TSP. Controls with no inoculation and/or no fertilizers were set throughout the experiments.

2.4. Sample Preparation. Three samples from each plot were taken randomly after seeds matured. The seeds were dried by direct sun drying. The seeds were cleaned manually to remove husks, damage seeds, and other extraneous materials. To determine the chemical composition, tannin, and in vitro protein digestibility, the cleaned seeds were ground to pass a $0.4 \mathrm{~mm}$ sieves.

2.5. Total Mineral Determination. Minerals were extracted from the samples by the dry-ashing method described by 
Walsh [19]. About $1.0 \mathrm{~g}$ sample was acid-digested with diacid mixture $\left(\mathrm{HNO}_{3}: \mathrm{HClO}_{4}, 5: 1, \mathrm{v} / \mathrm{v}\right)$ in a digestion chamber. The digested samples were dissolved in double-distilled water and filtered (Whatman No. 42). The filtrate was made to $50 \mathrm{~mL}$ with double-distilled water and was used for the determination of total minerals. The amounts of iron, zinc, manganese, and copper were determined using atomic absorption spectroscopy (Perkin-Elmer 2380, USA). Calcium and magnesium were determined by the titration method described by Chapman and Pratt [20]. Sodium and potassium were determined using a flame photometer (CORNIG EEL, London, UK) according to the AOAC [21] method.

2.6. Statistical Analysis. Experimental data were analyzed by using the general linear models procedure, the ANOVA procedure, and Duncan's multiple range tests (SAS Software Inst. Inc., Cary, N.C., USA). Least significant differences were computed at $P \leq 0.05$. Data were also analyzed using the correlation procedure (Pearson's correlation coefficients) in SAS.

\section{Results and Discussion}

In Africa, most farmers grow two or more crops (usually legumes in mixture with cereals) simultaneously on the same field in an effort to improve food security and their livelihoods using the available insufficient resources. The determination of minerals and trace elements in foodstuffs is an important part of nutritional and toxicological analyses. Thus, the present study was aimed at understanding the status of minerals concentration in the seeds of sorghum growing as crop components in sole or mixed culture as affected by inoculation with Bradyrhizobium strain, $\mathrm{N}$ and $\mathrm{P}$ fertilization. The results of the present study revealed various differences in the minerals content of sorghum seeds as affected by different treatments. Intercropping did not affect the $\mathrm{P}$ content of sorghum seeds in the first season and slightly increased P content in the second season (Figure 1(a)). In agreement with our results, growing cowpea in mixed culture with sorghum has been found to decrease the concentrations of $\mathrm{P}$ in the rhizosphere of cowpea plants, leading to markedly decreased content in tissues [22]. In contrast, it has been reported that intercropping increased the $\mathrm{P}$ concentrations of intercropped peanut and maize plants [23]. Although, all the treatments did not affect the concentration of $\mathrm{P}$ in the second season, their effect is fluctuated in the first season, whereas the Bradyrhizobium inoculation significantly $(P \leq 0.05)$ decreased the $\mathrm{P}$ content of sorghum seeds in intercropping system in the first seasons as compared to untreated control. However, application of $20 \mathrm{~kg} \mathrm{~N} / \mathrm{ha}$ alone or combined with Bradyrhizobium slightly increased the P content of monocropped sorghum seeds in the first season. These treatments slightly decreased the $\mathrm{P}$ content of intercropped sorghum seeds in the first season. Similarly, it has been reported that inoculation with the locally isolated strains (ENRRI 16A and ENRRI 16C) as well as the introduced strains (TAL 169 and TAL 1371) of
Bradyrhizobium failed to make significant increase in the mean P content of guar seeds [24]. Unlikely, application of $50 \mathrm{~kg} \mathrm{P} / \mathrm{ha}$ alone or together with Bradyrhizobium slightly increased $\mathrm{P}$ content in monocropped plant in first season, whereas, these treatments had no effect on P content in intercropped sorghum seeds. It is clear from untreated control (Figure 1(b)) that intercropping significantly $(P \leq 0.05)$ increased the Ca content of sorghum seeds in both seasons. By contrast, significant reduction of Ca concentrations of intercropped peanut and maize was reported [23]. Moreover, growing cowpea in mixed culture with sorghum significantly decreased the concentrations of $\mathrm{Ca}$ content in the rhizosphere and tissues of cowpea plants [22]. All treatments significantly $(P \leq 0.05)$ affected the Ca concentration in the first season of both cropping systems. Application of $20 \mathrm{~kg} \mathrm{~N} /$ ha significantly $(P \leq 0.05)$ increased the Ca content of sorghum seeds in the two seasons in monocropping system, whereas it insignificantly increased the Ca content in the two seasons in intercropping system compared to the untreated controls. Bradyrhizobium inoculation had no significant effect on Ca content in monocropped sorghum seeds in both seasons, while it significantly $(P \leq 0.05)$ enhanced Ca content in intercropped seeds in both seasons. In monocropping system, Bradyrhizobium inoculation and $\mathrm{N}$ fertilization significantly $(P \leq 0.05)$ enhanced the $\mathrm{Ca}$ content in both seasons. Application of $50 \mathrm{~kg} \mathrm{P} / \mathrm{ha}$ alone or in combination with Bradyrhizobium significantly $(P \leq 0.05)$ increased the concentration of $\mathrm{Ca}$ in the first season of both cropping systems, whereas the effect in the second season was fluctuated. Similarly, it has been reported that Bradyrhizobium inoculation significantly increased $\mathrm{Ca}$ content of guar genotypes $[24,25]$, hyacinth bean seeds [26], and soybean [27]. On the other hand, Elsheikh and Mohamedzein [28] reported that groundnut seed Ca content did not show any pattern in response to Bradyrhizobium and/or VA mycorrhiza. However, Kawai and Yamamoto [29] reported that inoculation with VAM increased plant development through supply of some elements such as Ca. Moreover, Giri [30] reported that application of $25 \mathrm{~kg} \mathrm{~N} / \mathrm{ha}$ to groundnut increased crop uptake of $\mathrm{Ca}$. The difference in response to such treatments could be attributed to the difference in cultivars as well as the growing environment.

Results on sodium $(\mathrm{Na})$, potassium $(\mathrm{K})$, and magnesium $(\mathrm{Mg})$ contents are presented in Figure 2. As could be seen from untreated controls, intercropping did not affect $\mathrm{Na}$ content of sorghum seeds in both seasons (Figure 2(a)). Although, application of $20 \mathrm{~kg} \mathrm{~N} /$ ha significantly $(P \leq 0.05)$ reduced the content of $\mathrm{Na}$ in monocropped sorghum seeds, this treatment significantly $(P \leq 0.05)$ increased $\mathrm{Na}$ concentration in intercropped seeds in both seasons. In monocropping system, Bradyrhizobium inoculation did not affect the concentration of $\mathrm{Na}$ in the sorghum seeds in both seasons, whereas it significantly increased the mineral content in the first season of monocropped seeds. The results of other treatments were fluctuated in the two cropping systems in both seasons. It has recently been reported that inoculation with Bradyrhizobium strain TAL 377 significantly increased $\mathrm{Na}$ content of monocropped soybean [27] and hyacinth bean [26]. However, previously, Elsheikh 


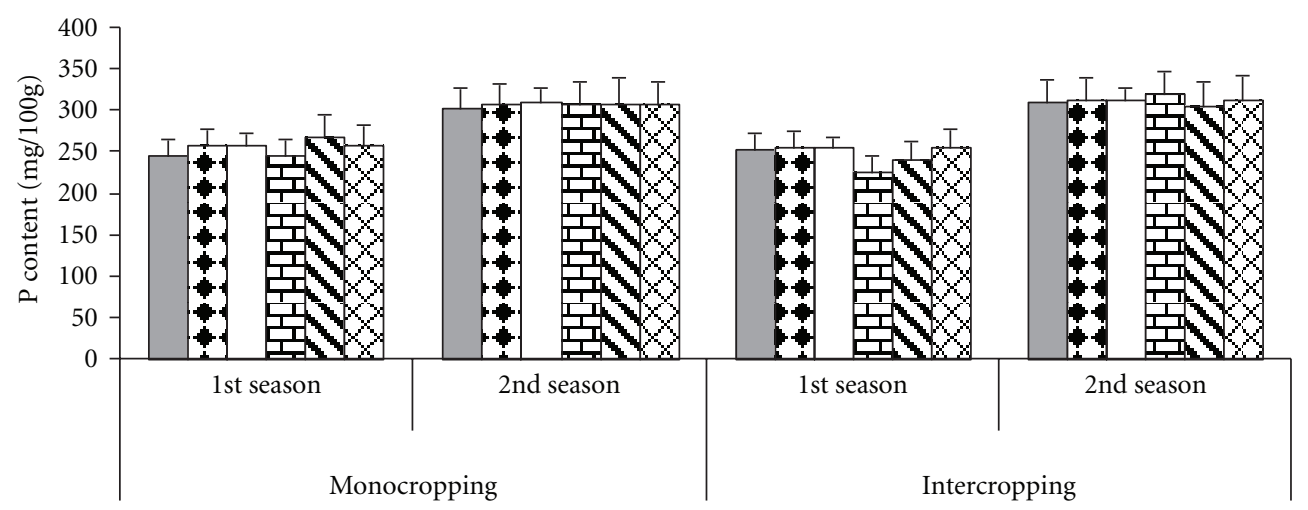

(a)

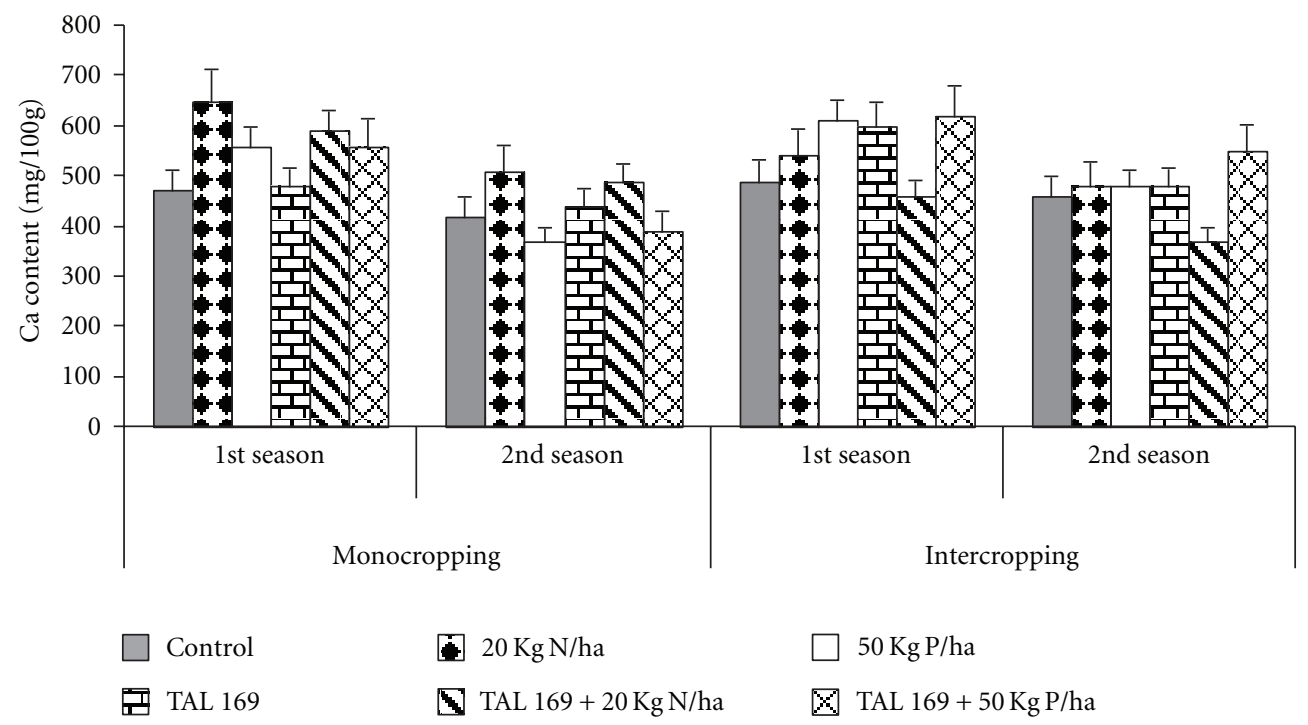

(b)

FIGURE 1: Effect of inoculation, N, P, and intercropping (sorghum/cowpea) on phosphorus (a) and calcium (b) contents of rainfed sorghum seeds grown for two consecutive seasons.

and Ibrahim [25] reported that inoculation insignificantly affected $\mathrm{Na}$ contents of guar cultivars. The difference in response to such treatments could also be attributed to the difference in cultivars as well as the growing environment. All treatments either did not affect or slightly decreased the $\mathrm{K}$ content of sorghum seeds compared to the untreated control in the two cropping systems in the two seasons (Figure 2(b)). Intercropping also did not affect the $\mathrm{K}$ content in both seasons. Recently, Makoi [22] reported that growing cowpea in mixed culture with sorghum significantly decreased the concentrations of $\mathrm{K}$ content in the rhizosphere and tissues of cowpea plants. Moreover, it has been reported that $\mathrm{K}$ concentration of wheat was decreased significantly by intercropping with chickpea or lentil [31]. Inconsistent with our results, Inal et al. [23] reported that intercropping significantly enhanced $\mathrm{K}$ concentrations of the plants when compared to the monocropping system. Moreover, Bradyrhizobium inoculation and fertilization by chicken manure were reported to increase $\mathrm{K}$ content of the soybean seeds in both cropping systems [27]. Intercropping slightly enhanced the concentration of $\mathrm{Mg}$ in the sorghum seeds in both growing seasons (Figure 2(c)). With exception to fertilization with $20 \mathrm{~kg}$ N/ha which slightly increased $\mathrm{Mg}$ concentration in the second season of intercropped sorghum seeds, all treatments significantly reduced the content of $\mathrm{Mg}$ in both cropping systems and both seasons. Recently, Makoi [22] reported that growing cowpea in mixed culture with sorghum significantly decreased the concentrations of $\mathrm{Mg}$ in the rhizosphere of cowpea plants, leading to markedly decreased content in tissues. By contrast, Elsheikh et al. [27] reported that inoculation with Bradyrhizobium strain TAL 377 and addition of chicken manure significantly increased $\mathrm{Mg}$ in intercropping system. Previously, Elsheikh and Ibrahim [25] reported that inoculation with Bradyrhizobium strains significantly increased $\mathrm{Mg}$ content of five cultivars of guar seeds. Moreover, Ibrahim et al. [26] indicated that fertilization of hyacinth bean by chicken manure or sulphur greatly increased $\mathrm{Mg}$ content of the crop seeds. Elsheikh and Mohamedzein [28] reported that inoculation with Bradyrhizobium and/or VA mycorrhiza significantly increased the seed content of Mg. This discrepancy of result suggests that different genotypes under different agronomic practices may 


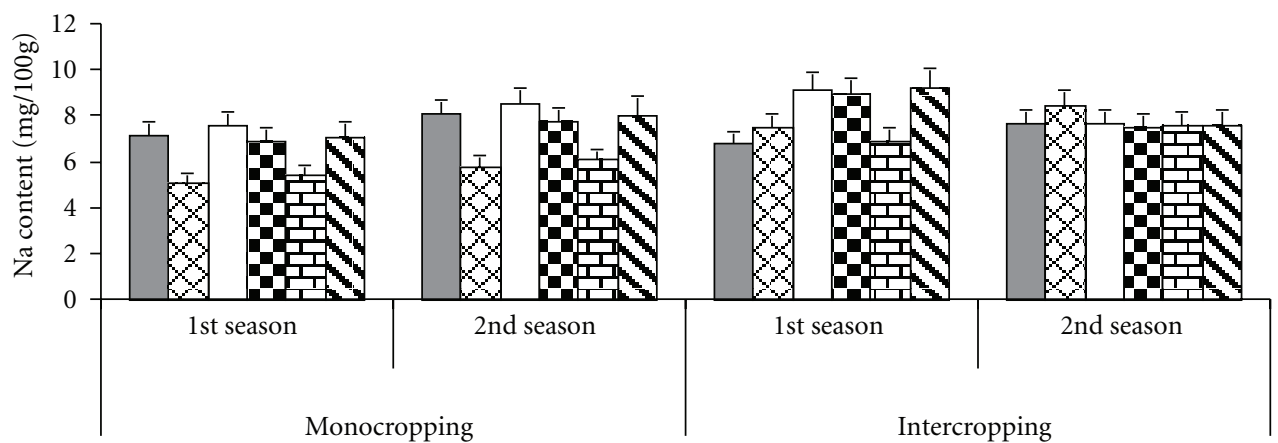

(a)

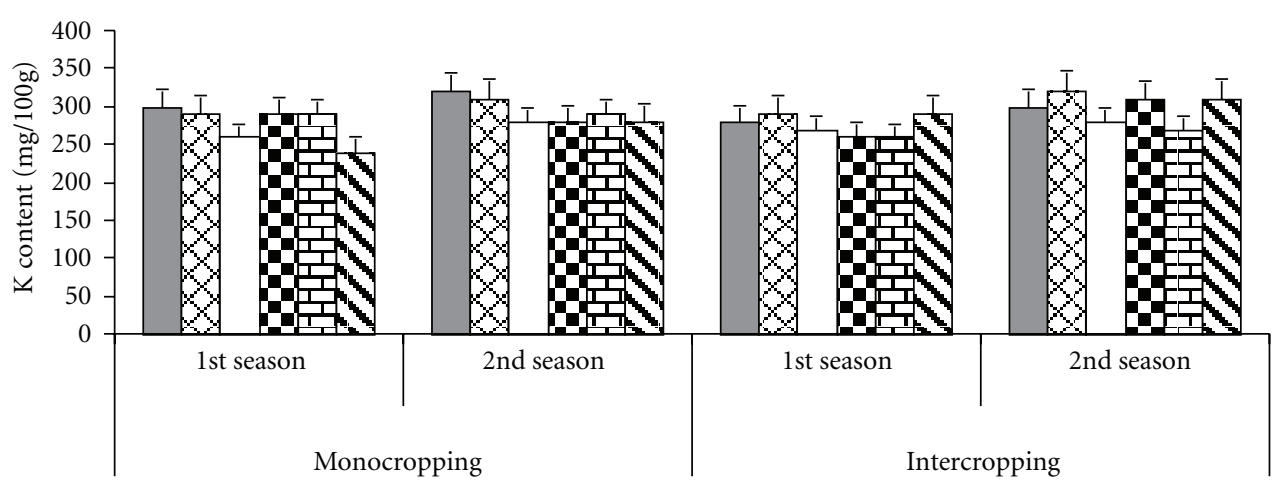

(b)

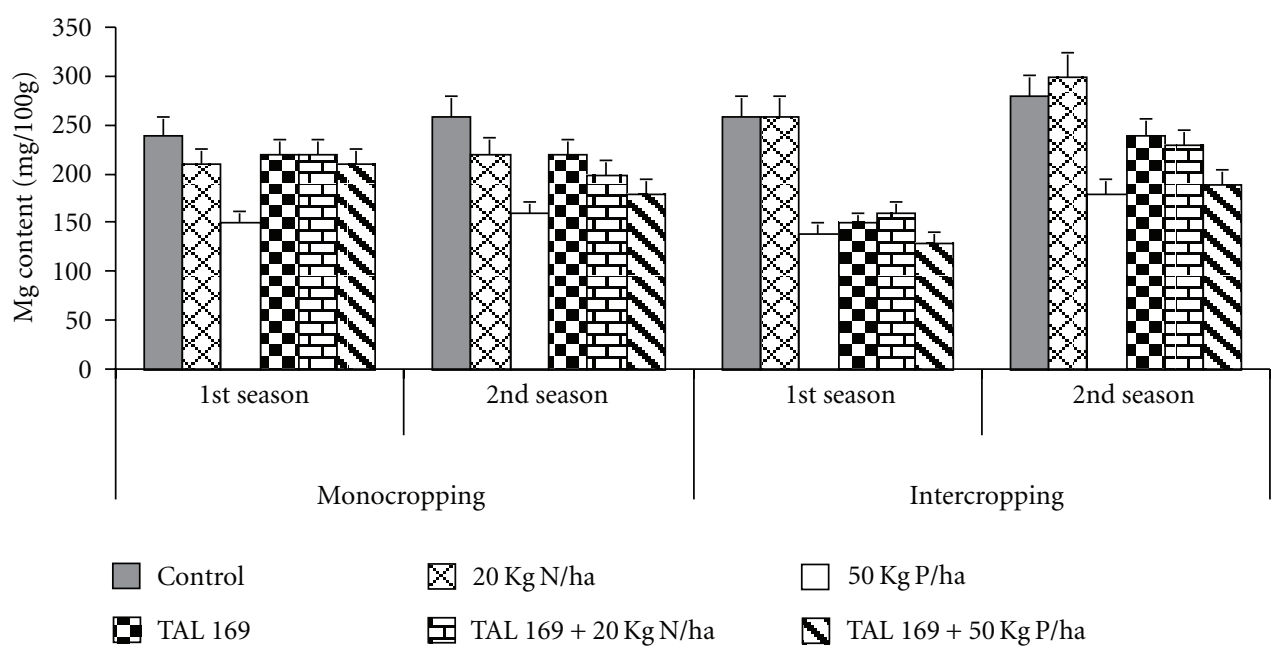

(c)

Figure 2: Effect of inoculation, N, P, and intercropping (sorghum/cowpea) on sodium (a), potassium (b), and magnesium (c) contents of sorghum seeds grown for two consecutive seasons.

lead to significant variation in the concentration of mineral element in the plant tissues and seeds.

Micronutrient deficiency in plant foods is becoming an increasingly important global problem. Proper metal transport and improvement in micronutrient content in the edible portions of the plant will be helpful for alleviating human nutritional disorders. Results on zinc $(\mathrm{Zn})$ and copper $(\mathrm{Cu})$ content in the seeds of cowpea under different cropping systems combined with various treatments are presented in Figure 3. Intercropping did not affect the content of $\mathrm{Zn}$ in the seeds sorghum plant of both growing seasons (Figure 3(a)). Moreover, Bradyrhizobium inoculation also did not affect the content of $\mathrm{Zn}$ in sorghum seeds in both cropping systems and both seasons. In the literature different effects of intercropping on the content of $\mathrm{Zn}$ have been reported. Reduction of $\mathrm{Zn}$ content in the tissues of cowpea plants growing in mixed culture with sorghum has been reported [22]. Whereas, intercropping enhanced $\mathrm{Zn}$ contents of intercropped wheat/chickpea under field condition [31] and peanut/graminoid species (wheat, maize, parley, oats) under greenhouse condition [23, 32]. All treatments of inoculation with Bradyrhizobium and $\mathrm{N}$ 


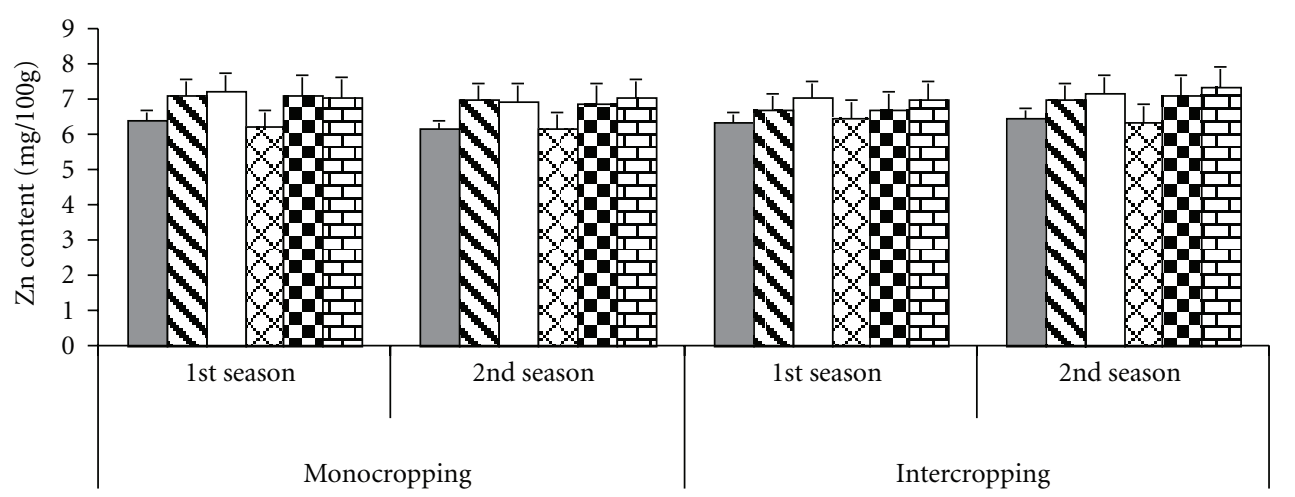

(a)

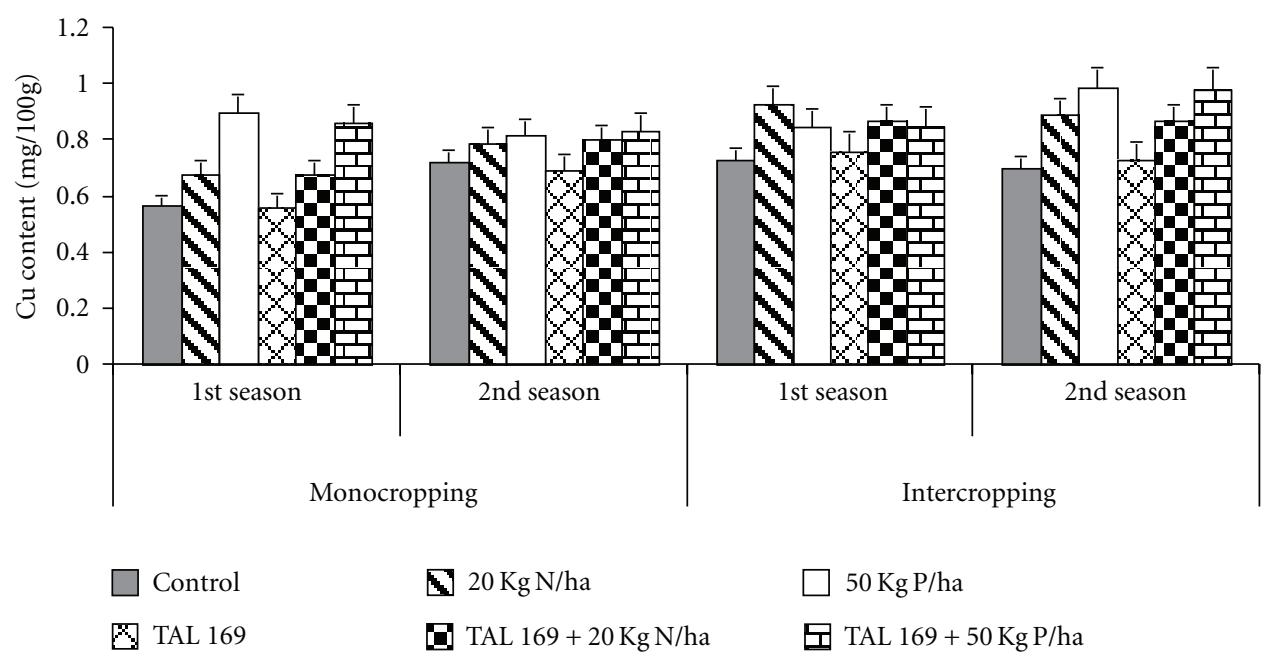

(b)

FIgURE 3: Effect of inoculation, N, P, and intercropping (sorghum/cowpea) on zinc (a) and copper (b) contents of rainfed sorghum seeds grown for two consecutive seasons.

and P fertilization showed similar effect on $\mathrm{Zn}$ content of sorghum seeds in both cropping systems of the two seasons. Inoculation with Bradyrhizobium did not affect the content of $\mathrm{Zn}$ in sorghum seeds in both cropping systems and both seasons, whereas fertilization with $\mathrm{N}$ and $\mathrm{P}$ alone or in combination with Bradyrhizobium inoculation slightly increased $\mathrm{Zn}$ content in the sorghum seeds of both cropping systems in the two seasons. Recently, Elsheikh et al. [27] reported that inoculation Bradyrhizobium strain TAL 377 significantly increased $\mathrm{Zn}$ of soybean seeds in monocropping system and insignificantly increased this mineral of intercropped soybean seeds. Previously, Elsheikh and Ibrahim [25] reported that inoculation with Bradyrhizobium strains significantly increased $\mathrm{Zn}$ content of five cultivars of guar seeds. Intercropping slightly increased the $\mathrm{Cu}$ content of sorghum seeds in the two seasons (Figure $3(\mathrm{~b})$ ). It has been reported that growing cowpea in mixed culture with sorghum significantly decreased the concentrations of $\mathrm{Cu}$ in the tissues of cowpea plants [22]. This discrepancy of result might be due to differences of cowpea genotypes and growing location and agronomic practices, which assumed to lead to significant variation in the concentration of mineral element in the plant tissues and seeds. The $\mathrm{Cu}$ content of monocropped sorghum seeds significantly $(P \leq 0.05)$ increased by application of $50 \mathrm{~kg}$ P/ha either alone or combined with Bradyrhizobium strain TAL 169 compared to the untreated control in both seasons. Recently, Elsheikh et al. [27] reported that inoculation with Bradyrhizobium strains and addition of chicken manure significantly increased $\mathrm{Cu}$ of soybean seeds in monocropping system. It has also been reported that inoculation with Bradyrhizobium strains had no significant effect on $\mathrm{Cu}$ content of guar cultivars [25].

Results of manganese $(\mathrm{Mn})$ and iron $(\mathrm{Fe})$ content of the cowpea seeds under different treatments and cropping systems are shown in Figure 4. Intercropping significantly $(P \leq 0.05)$ increased the Mn content of sorghum seeds in the first season and significantly $(P \leq 0.05)$ decreased it in the second season (Figure 4(a)). Similarly, Inal et al. [23] found that $\mathrm{Mn}$ concentration of peanut grown with maize increased significantly while the Mn concentrations of maize remained unchanged in response to intercropping. Moreover, under the field conditions, shoot concentration of $\mathrm{Mn}$ in wheat and chickpea was also reported to increase by intercropping [31]. With the exception of Bradyrhizobium treatment alone, all other treatments significantly $(P \leq 0.05)$ increased the $\mathrm{Mn}$ content of sorghum seeds compared to the untreated control 


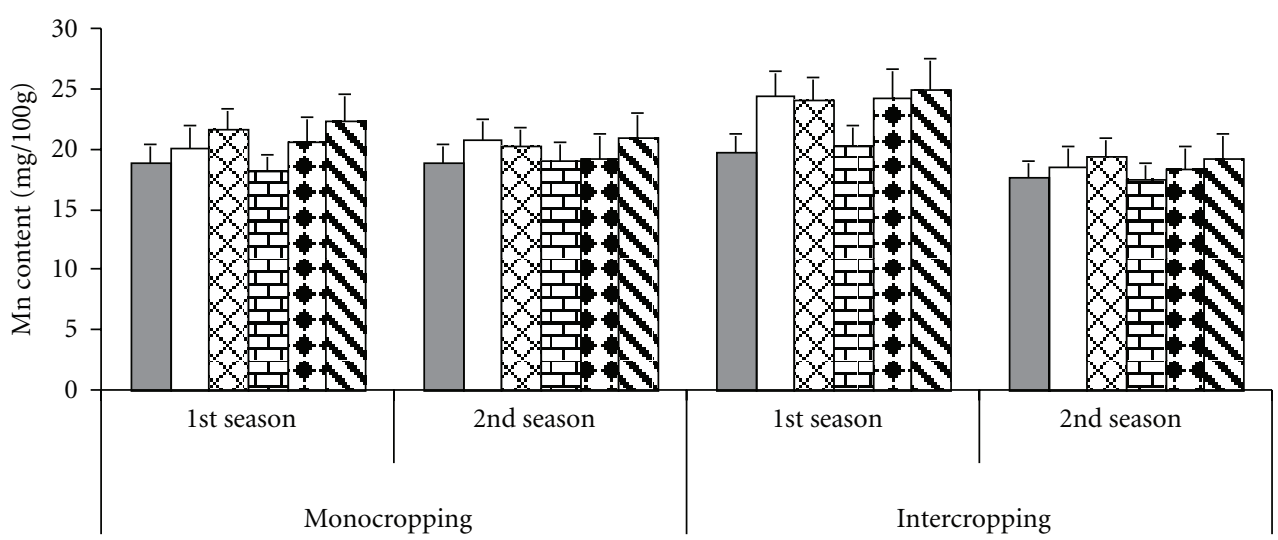

(a)

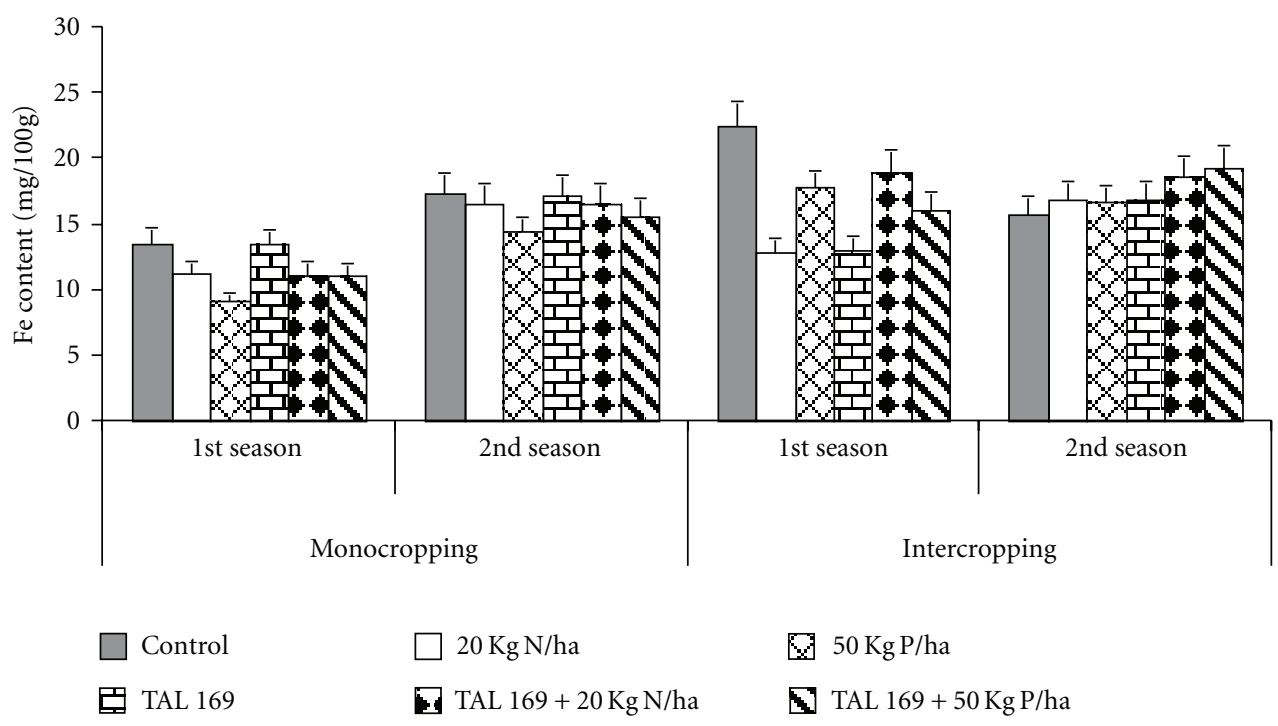

(b)

Figure 4: Effect of inoculation, N, P, and intercropping (sorghum/cowpea) on manganese (a) and iron (b) contents of rainfed sorghum seeds grown for two consecutive seasons.

in the first season of the two cropping systems. In the intercropped sorghum seeds the amount of Mn varied between the two seasons. Intercropping did not affect the content of Fe in both seasons compared to untreated control. As could be seen from untreated control, intercropping significantly $(P \leq 0.05)$ increased the Fe content of sorghum seeds in the two seasons (Figure 4(b)). All treatments significantly $(P \leq 0.05)$ decreased the Fe content of sorghum seeds in both cropping systems compared to the untreated control, in the first season. Bradyrhizobium strain when combined with $20 \mathrm{~kg} \mathrm{~N} / \mathrm{ha}$ or $50 \mathrm{~kg} \mathrm{P} /$ ha significantly $(P \leq 0.05)$ increased the $\mathrm{Fe}$ content of intercropped sorghum seeds in the second season. In agreement with our results, Zuo and Zhang [32] reported that in the intercropping systems of two maize genotypes, barley, oats, and wheat not only acquired adequate $\mathrm{Fe}$ to meet their own demand, but also improved the Fe status of peanut. On the other hand, it has been reported that growing cowpea in mixed culture with sorghum significantly decreased the concentrations of
Fe in the rhizosphere of cowpea plants, leading to markedly decreased content in tissues [22]. However, insignificant improvements of Fe nutrition of intercropped wheat and chickpea were also reported [31]. This discrepancy of the results might be due to the variation in the plants genotypes as well as agronomical practices and locations. Generally, grain legumes contain all of the essential minerals required by human, although concentration may vary in response to both genetic and environmental factors [33].

Overall, our results demonstrated that intercropping, Bradyrhizobium inoculation, and $\mathrm{N}$ and $\mathrm{P}$ fertilization had significant effect on the mineral status of sorghum seeds. Intercropping significantly $(P \leq 0.05)$ increased $\mathrm{Ca}, \mathrm{Mg}, \mathrm{Cu}$, $\mathrm{Mn}$, and Fe contents of sorghum seeds, while it had no effect on the concentration of $\mathrm{P}, \mathrm{K}, \mathrm{Na}$, and $\mathrm{Zn}$ in the sorghum seeds. Bradyrhizobium inoculation did not enhance the minerals content of sorghum in both cropping systems. In previous study Obied [34] found that inoculation increased the mineral content of $\mathrm{Ca}, \mathrm{Mg}, \mathrm{K}, \mathrm{Na}, \mathrm{Fe}, \mathrm{Cu}, \mathrm{Zn}$, and $\mathrm{Mn}$ 
of soybean and hyacinth bean seeds. Moreover, Salih [35] found that inoculation of soybean significantly increased $\mathrm{Cu}$, $\mathrm{K}, \mathrm{Mn}$, and $\mathrm{Zn}$ content of intercropped sorghum seeds.

Several minerals such as $\mathrm{Ca}, \mathrm{Fe}, \mathrm{K}, \mathrm{Mo}, \mathrm{Na}, \mathrm{Ni}$, and $\mathrm{P}$ are essential for human and animal health. The knowledge about their level in different raw foods provides information on the nutritional adequacy of diets. Other minerals such as $\mathrm{Cu}$, Se, and $\mathrm{Zn}$ are essential; however, they have a limited range between required and toxic levels. Minerals content of leguminous seeds vary with different cropping, inoculation, and fertilization treatments.

\section{Conclusion}

Combined intercropping and biofertilization could overcome potential nutrient deficiencies, particularly in harvested seeds, and the value of such agronomic arrangements is very important for countries that cannot afford biotechnological research and where farmers are often forced to rely on their own inexpensive seed resources. The results of our experiments strongly support that the sorghum intercropped with cowpea and treated with chemical and/or biofertilization could enhance critical macro- and micronutrients $(\mathrm{Ca}$, $\mathrm{Mg}, \mathrm{Cu}, \mathrm{Mn}$, and $\mathrm{Fe}$ ) of sorghum seeds. Proper agronomical programmes, focusing on biofertilization and intercropping, should be implemented to improve the productivity of food cereals and thereby increase total food production, improve the supply of good quality proteins as well as minerals in the diet of people who largely depend on food cereal crops, and improve seed quality. The latter implies processing, consumer, nutritional value, and export quality. This investigation also calls food scientists to allow for the previous agronomic treatments, the history of the seeds, their origin and certification, before starting their experiments, analysis, or interpreting their data. Furthermore, increasing mineral nutrient concentration of the seed is a high priority research task and will greatly contribute to alleviation of micronutrient deficiencies in human populations worldwide.

\section{Disclosure}

This study was privately supported and no funding agency and/or persons to acknowledge. The authors of this paper do not have a direct financial relation with the commercial identity mentioned in the paper.

\section{References}

[1] S. Bhupinder, U. Kalidindi, B. Singh, and K. Usha, "Nodulation and symbiotic nitrogen fixation of cowpea genotypes as affected by fertilizer nitrogen," Journal of Plant Nutrition, vol. 26, no. 2, pp. 463-473, 2003.

[2] R. W. Willey, "Resource use in intercropping systems," Agricultural Water Management, vol. 17, no. 1-3, pp. 215-231, 1990.

[3] M. J. Potts, "Influence of intercropping in warm climates on pests and diseases of potato, with special reference to their control," Field Crops Research, vol. 25, no. 1-2, pp. 133-144, 1990.
[4] C. W. Campbel, "Tehniques for producing export-quality, tropical horticultural crops," Horticultural Science, vol. 25, pp. 31-33, 1990.

[5] D. J. Finney, "Intercropping experiments, statistical analysis, and agricultural practice," Experimental Agriculture, vol. 26, no. 1, pp. 73-81, 1990.

[6] J. Vandermeer, The Ecology of Intercropping, Cambridge University Press, 1989.

[7] K. Fujita, K. G. Ofosu-Budu, and S. Ogata, "Biological nitrogen fixation in mixed legume-cereal cropping systems," Plant and Soil, vol. 141, no. 1-2, pp. 155-175, 1992.

[8] R. Sangakkara, "Growth, yield and nodule activity of mungbean intercropped with maize and cassava," Journal of the Science of Food and Agriculture, vol. 66, no. 3, pp. 417-421, 1994.

[9] I. C. Onwueme and I. D. Sinha, Field Crop Production in Tropical Africa, CTA, The Netherlands, 1993.

[10] M. M. Ahmed, J. H. Sanders, and W. T. Nell, "New sorghum and millet cultivar introduction in sub-saharan Africa: impacts and research agenda," Agricultural Systems, vol. 64, no. 1, pp. 55-65, 2000.

[11] N. Seetharama, S. Singh, and B. V. S. Reddy, "Strategies for improving rabi sorghum productivity," Proceedings of the Indian National Science Academy, vol. 56, no. 5-6, pp. 455-467, 1990.

[12] FAO/WFP, "Special report FAO/WFP crop and food supply assessment mission to Sudan," 2007.

[13] A. A. Mahdi and E. M. A. Mustafa, "Response of Guar to Bradyrhizobium inoculation and to nitrogen and phosphate fertilization," Journal of Agricultural Sciences, vol. 13, no. 1, pp. 97-110, 2005.

[14] E. E. Babiker, E. A. E. ElSheikh, A. J. Osman, and A. H. El Tinay, "Effect of nitrogen fixation, nitrogen fertilization and viral infection on yield, tannin and protein contents and in vitro protein digestibility of faba bean," Plant Foods for Human Nutrition, vol. 47, no. 3, pp. 263-275, 1995.

[15] E. A. E. Elsheikh and A. A. Elzidany, "Effect of Rhizobium inoculation, organic and chemical fertilizers on proximate composition, in vitro protein digestibility (IVPD), tannin and sulphur content of faba beans," Food Chemistry, vol. 59, no. 1, pp. 41-45, 1997.

[16] G. U. Okereke and C. C. Onochie, "Short communication: screening of native and foreign Bradyrhizobium japonicum strains for high $\mathrm{N}_{2}$ fixation in soybean," World Journal of Microbiology and Biotechnology, vol. 12, no. 6, pp. 639-641, 1996.

[17] W. C. Lindemann, J. J. Aburto, W. M. Haffner, and A. A. Bono, "Effect of sulfur source on sulfur oxidation," Soil Science Society of America Journal, vol. 55, no. 1, pp. 85-90, 1991.

[18] A. Ghani, J. H. Watkinson, and M. P. Upsdell, "Modeling the oxidation of elemental sulphur in New Zealand pastoral soils," Sulphur in Agriculture, vol. 20, pp. 3-9, 1997.

[19] L. M. Walsh, Instrumental Methods for Analysis of Soils and Plant Tissues, Soil Science Society of America, Madison, Wis, USA, 2nd edition, 1980.

[20] H. D. Chapman and F. P. Pratt, "Ammoniumn vandatemolybdate method for determination of phosphorus," in Methods of Analysis for Soils, Plants and Water, pp. 184-203, California University, Agriculture Division, Oakland, Calif, USA, 1st edition, 1961.

[21] AOAC, Official Methods of Analysis, Association of Official Analytical Chemistry, Washington, DC, USA, 16th edition, 1995. 
[22] J. H. J. R. Makoi, Seed flavonoid concentration in cowpea genotypes and the effect of plant density on growth, $\mathrm{N}_{2}$ fixation and rhizosphere phosphatases and grain yield of cowpea intercropped with sorghum, Ph.D. thesis, Faculty of Applied Science, Cape Peninsula University of Technology, 2009.

[23] A. Inal, A. Gunes, F. Zhang, and I. Cakmak, "Peanut/maize intercropping induced changes in rhizosphere and nutrient concentrations in shoots," Plant Physiology and Biochemistry, vol. 45, no. 5, pp. 350-356, 2007.

[24] K. A. Ibrahim, K. H. Suliman, and A. A. Abdalla, "Influence of inoculation with some Bradyrhizobium strains on yield attributes, seedproximate composition and minerals content of guar (Cyamopsis teteragonolopa L.) grown in Sudan," Australian Journal of Basic and Applied Sciences, vol. 4, no. 5, pp. 808-816, 2010.

[25] E. A. E. Elsheikh and K. A. Ibrahim, "The effect of Bradyrhizobium inoculation on yield and seed quality of guar (Cyamopsis tetragonoloba L.)," Food Chemistry, vol. 65, no. 2, pp. 183-187, 1999.

[26] K. A. Ibrahim, E. A. E. Elsheikh, and E. E. Babiker, "Bradyrhizobium inoculation and chicken manure or sulphur fertilization of hyacinth bean (Dolichos hyacinth L.): changes in physical characteristics and chemical composition of the seeds," Australian Journal of Basic and Applied Sciences, vol. 2, no. 3, pp. 605-616, 2008.

[27] E. A. E. Elsheikh, S. S. M. Salih, A. A. Elhussein, and E. E. Babiker, "Effects of intercropping, Bradyrhizobium inoculation and chicken manure fertilisation on the chemical composition and physical characteristics of soybean seed," Food Chemistry, vol. 112, no. 3, pp. 690-694, 2009.

[28] E. A. E. Elsheikh and E. M. M. Mohamedzein, "Effect of Bradyrhizobium, VA mycorrhiza and fertilisers on seed composition of groundnut," Annals of Applied Biology, vol. 132, no. 2, pp. 325-330, 1998.

[29] Y. Kawai and Y. Yamamoto, "Increase in the formation and nitrogen fixation of soybean nodules by vesicular-arbuscular mycorrhiza," Plant and Cell Physiology, vol. 27, no. 3, pp. 399405, 1986.

[30] G. Giri, "Direct and residual effect of nitrogen and phosphorus fertilization on groundnut (Arachis hypogaea) and Wheat (Triticum aestivum) cropping system," Indian Journal of Agronomy, vol. 38, pp. 6-12, 1993.

[31] A. Gunes, A. Inal, M. S. Adak et al., "Mineral nutrition of wheat, chickpea and lentil as affected by mixed cropping and soil moisture," Nutrient Cycling in Agroecosystems, vol. 78, no. 1, pp. 83-96, 2007.

[32] Y. Zuo and F. Zhang, "Effect of peanut mixed cropping with gramineous species on micronutrient concentrations and iron chlorosis of peanut plants grown in a calcareous soil," Plant and Soil, vol. 306, no. 1-2, pp. 23-36, 2008.

[33] T. L. Wang, C. Domoney, C. L. Hedley, R. Casey, and M. A. Grusak, "Can we improve the nutritional quality of legume seeds?” Plant Physiology, vol. 131, no. 3, pp. 886-891, 2003.

[34] K. A. I. Obied, Effects of Bradyrhizobium, chicken manure, sulphur and their residual effect on nodulation, growth, yield and seed quality of soybean and hyacinth bean, Dissertation for the Doctoral Degree, University of Khartoum, 2003.

[35] S. S. M. Salih, Symbiotic nitrogen fixation and chicken manure fertilization in soy bean/ sorghum intercropping system, Dissertation for the Doctoral Degree, University of Khartoum, 2002. 


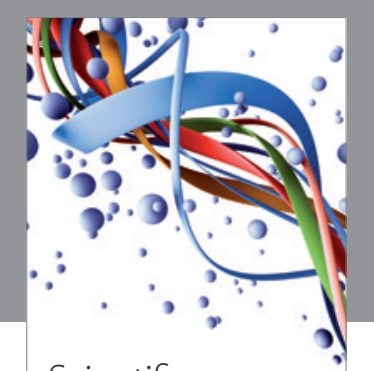

Scientifica
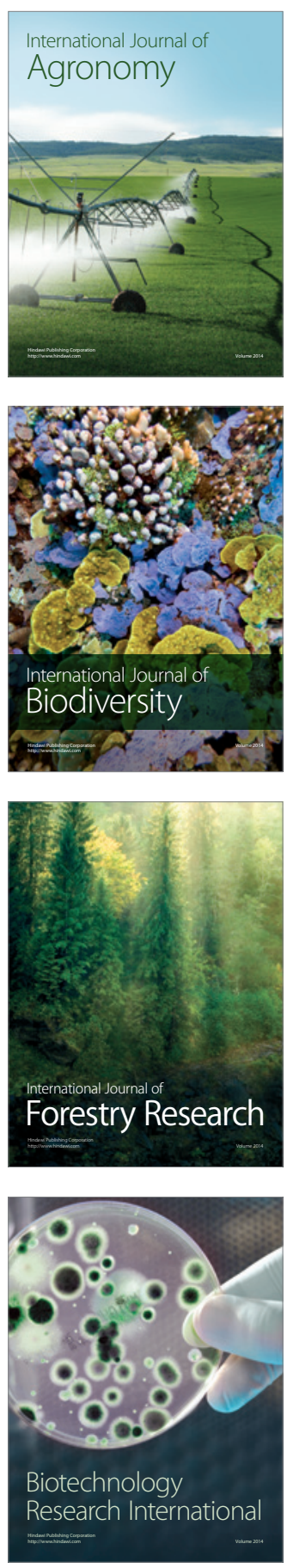
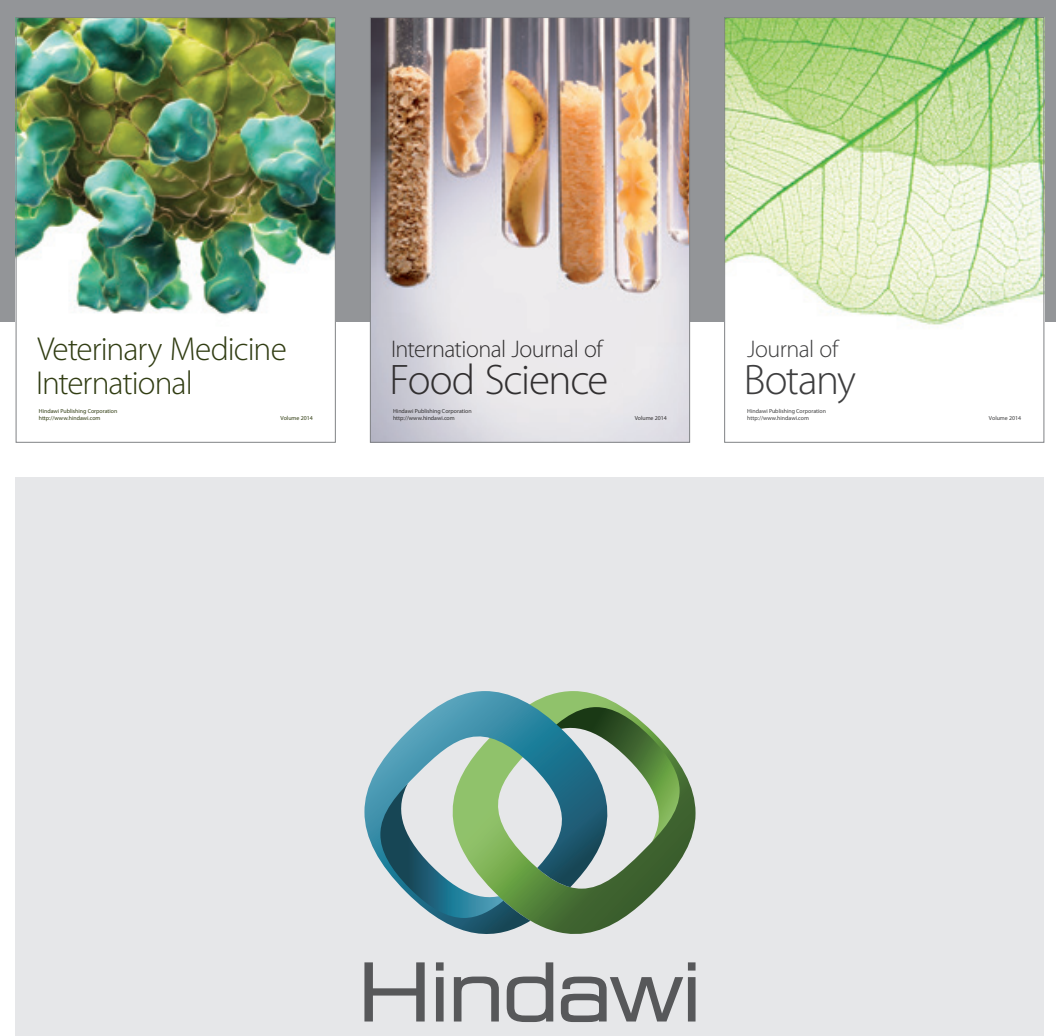

Submit your manuscripts at

http://www.hindawi.com
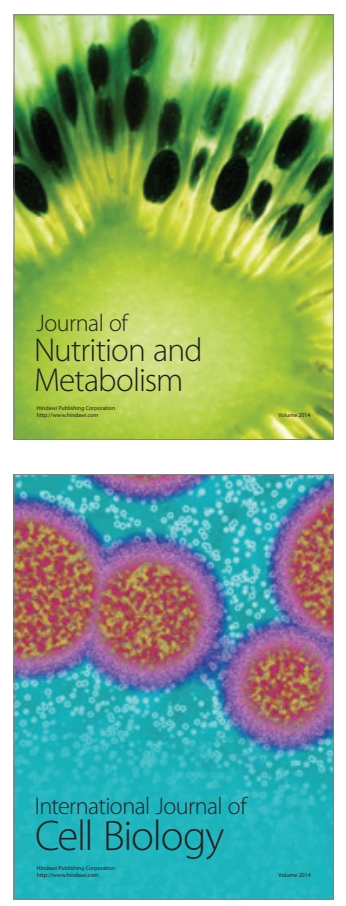
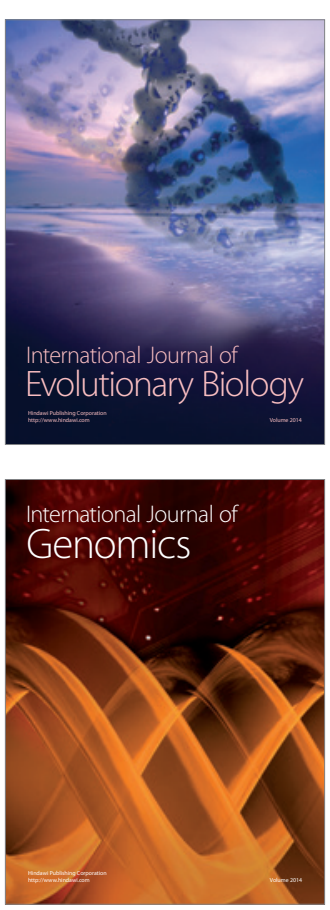
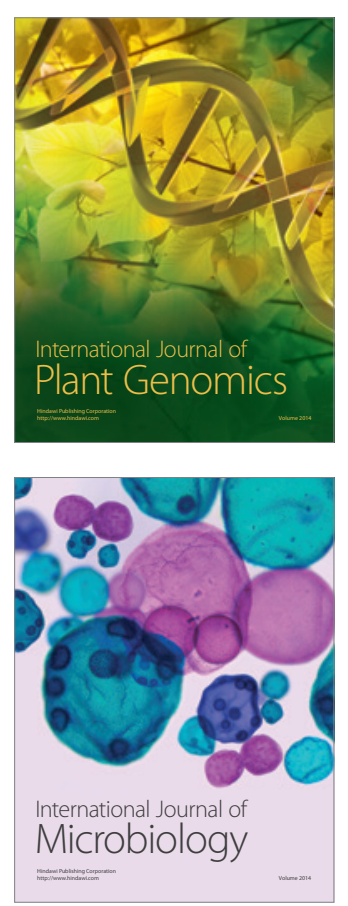

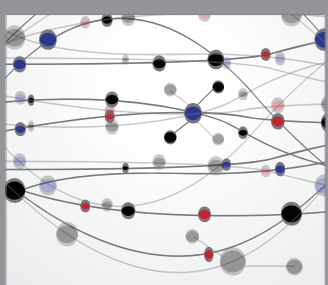

The Scientific World Journal
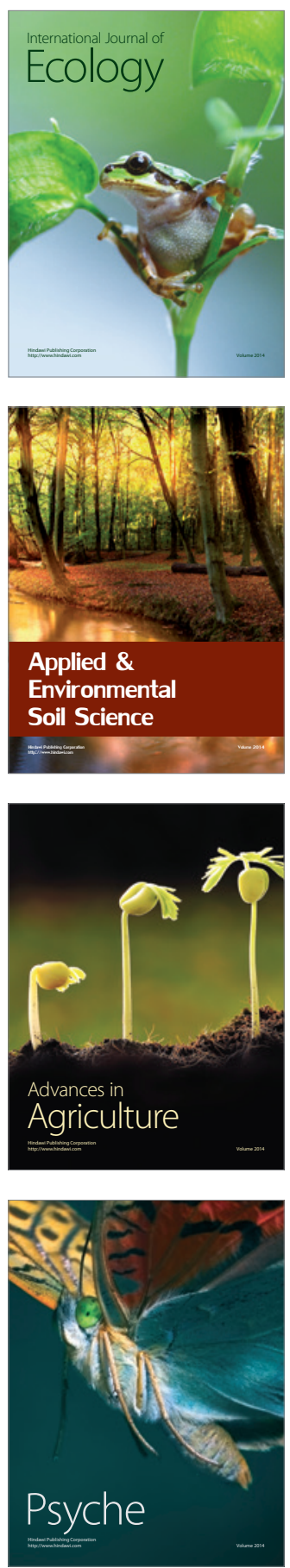